\title{
Political Education and Democracy System in the City of Semarang
}

\author{
Karmanis $^{1}$, Suparno ${ }^{2}$ \\ \{suparno.untag.smg@gmail.com ${ }^{2}$ \} \\ Universitas 17 Agustus 1945 Semarang, Indonesia ${ }^{1,2}$
}

\begin{abstract}
Indonesia as a democracy, the highest power in the hands of the people. The success of elections is carried out directly, openly, freely and secretly. This pattern is an indicator in a country that operates a democratic system. The voice of the people in a democratic country is a very valuable value because the people determine the government. In this research, the researcher formulates the political education strategy in the democratic system in Semarang City? by using descriptive qualitative research methods. This research was conducted in Semarang City, Central Java. Research Results: The government has an important role in providing political education in society. Political education focuses on civic education, which is education that can arouse nationalism, strengthen ideological awareness, and shape citizen behavior in accordance with national ideology. The government also has a constitutional duty to determine candidates for national leadership in the executive and legislative branches. Creating a conducive climate for the unity and integrity of the Indonesian nation. follow up, collect and channel the political aspirations of the community in planning, formulating and determining public policies. Recommendations: First, the quality of election administration needs to be improved. Second, the concept of E-Vote in direct elections needs to be considered, so that the implementation of elections is more efficient, effective, and minimizes manipulation of vote counts.
\end{abstract}

Keywords: Political Strategy, Political Education, Democracy

\section{Introduction}

The Indonesian state is adhering to a democratic system, in the exercise of its power based on the will of the people. Success in holding elections is directly, publicly, free and confidential, because this will be a measure of the value of successful implementation of democracy, the voice of the people in a democratic country is a very valuable value because the people determine the government itself. In Article 1 paragraph 2 of the 1945 Constitution, it is stated that political decision making must be based on the will of the people. One of the government's tasks is to organize political education to participate in realizing a democratic, critical and conscious society in a pluralistic society. Political education has the aim of increasing the abilities, skills of the community, both in terms of their knowledge and rights in life so that they become politically aware and responsible development people. Through elections the people elect the legislature as their representative to sit in parliaments and the executive as the government structure. The existence of the General Election of the people has the means to channel political rights to be elected or elect democratic government leaders, which is held once in five years. The Semarang City Government has the authority over 
general elections to have a political education program for the community in order to support the successful implementation of legislative elections, presidential and regional head elections.

Based on the background of the problem, it is necessary to carry out an academic study "Strategies of political education as increasing public participation in the democratic system in the city of Semarang".

\section{Research Method}

This research uses a descriptive qualitative approach. Data sources: Primary, (interview results and observations) and Secondary data sources (local legal products and literature books, as well as documents relating to the problem). Data collection techniques with interviews, and library research, and Fokus Group Disruption. Data analysis techniques using interactive model analysis, namely data reduction, data display and conclusion drawing. Data validity, using criteria, namely: Credibility, Transferability, Dependability, and Conformability.

\section{Literature Review}

\subsection{Political Education}

Political education is an effort to increase public knowledge so that they can participate maximally in their political system. Sovereignty of the people or democracy, the people must be able to carry out the task of participation. Rusadi [1] explains that forms of political education can be carried out through a variety of media, namely reading material, for example in the form of newspapers or magazines, audio-visual media in the form of radio broadcasts or through television, Community education institutions informal or formal, for example lectures delivered at mosques or churches. The legal basis for implementing political education in Indonesia is Pancasila and the 1945 Constitution.

\subsection{Political Participation}

Budiardjo [2], Explains that political participation is an activity carried out by a person or group of people who intend to take an active role in political life, among others by electing state leaders so that they can influence government policies either directly or indirectly (public policy). Other things can be in the form of holding relations with parliamentarians or government officials, attending general meetings, being a member of the party, and joining one of the social movements in the community and so on.

Al Muchtar and Suwarma [3] also explained that conventional forms of participation are normal participation in modern democracies, besides non- conventional forms of participation including those that may be legal or illegal, full of violence and revolutionary.

\subsection{Democratic}

A democratic country is a country that involves its people in determining government policy, so that the people as the highest authority in a country. Abdurrahman Rahman Assegaf 
[4] explains the origin of the word democracy, namely demos that defines the people, and kratos which defines power. Harris [5] explains something similar to the opinion of Abd. Rahman Assegaf, namely democracy is a form of people's government, in which the people are very instrumental in the power of government in a country.

\section{Result and Discussion}

\subsection{The Role of Government and Community Participation in the Democratic System}

The role of the government in political education, not only pay attention to the community at the time of the campaign or before the democratic party, but this political education activities need to take place continuously. The government must create a mutually beneficial relationship between the people and the elite in order to realize the nation's aspirations. According to Marbun [6] Education is the process of changing the attitudes and behavior of a person or group of people in an effort to kill humans with teaching and training efforts at the educational level plays an important role in absorption and communication skills.

Political Education is also a process of learning and understanding of the rights, obligations and responsibilities of every citizen in the life of the nation and state. If it is associated with the government, political education can be interpreted as a conscious and systematic effort in transforming everything related to the struggle of the government to the public so that they are aware of their roles and functions, as well as their rights and obligations as human beings or citizens.

Thus, there are three objectives of political education: forming political awareness, political personality, and political participation. Political education for the people of Semarang City is one of the keys in efforts to improve the democratic system. Information on political education regarding Presidential and Vice President Elections, regional head elections, legislative elections. Who has a role in political education? organizing political education, conducted by city government, Political Parties, Regional Election Commission and the Election Supervisory Body, mass media.

Post-election reforms have been held six times, starting from 1999, 2004, 2009, 2014, 2015, and in 2019. The Semarang City Election Commission reported voter participation from general elections which began from 2004 to the last in 2019.

Table 1. Voter Participation in Semarang City Elections 2004-2019

\begin{tabular}{|l|c|c|c|}
\hline \multicolumn{1}{|c|}{ Election } & Year & $\begin{array}{c}\text { Number of } \\
\text { Voters }\end{array}$ & $\begin{array}{c}\text { Voter } \\
\text { Participation }\end{array}$ \\
\hline $\begin{array}{l}\text { House of Representatives, Regional House of } \\
\text { Representatives, and Regional House of Representatives }\end{array}$ & 2004 & 1031392 & $78,69 \%$ \\
\hline Election of President and Vice President Round I & 2004 & 1076118 & $78,71 \%$ \\
\hline Election of President and Vice President Round II & 2004 & 1052047 & $78,60 \%$ \\
\hline Election of Mayor and Deputy Mayor of Semarang & 2005 & 997200 & $66,68 \%$ \\
\hline $\begin{array}{l}\text { Election of the Governor and Deputy Governor of } \\
\text { Central Java }\end{array}$ & 2008 & 1086521 & $62,74 \%$ \\
\hline
\end{tabular}




\begin{tabular}{|l|c|c|c|}
\hline $\begin{array}{l}\text { General Elections of the House of Representatives, the } \\
\text { Regional House of Representatives, and the Regional } \\
\text { House of Representatives }\end{array}$ & 2009 & 1087463 & $78,79 \%$ \\
\hline Election of President and Vice President & 2009 & 1094832 & $78,79 \%$ \\
\hline Election of Mayor and Deputy Mayor of Semarang & 2010 & 1100337 & $60,06 \%$ \\
\hline $\begin{array}{l}\text { Election of the Governor and Deputy Governor of } \\
\text { Central Java }\end{array}$ & 2013 & 1125696 & $61,44 \%$ \\
\hline $\begin{array}{l}\text { Election of Members of the People's Legislative } \\
\text { Assembly, the Regional Representative Council, and the } \\
\text { Regional People's Representative Council }\end{array}$ & 2014 & 1101290 & $75,15 \%$ \\
\hline Election of President and Vice President & 2014 & 1121824 & $79,88 \%$ \\
\hline Election of Mayor and Deputy Mayor of Semarang & 2015 & 1109045 & $65,67 \%$ \\
\hline $\begin{array}{l}\text { Election of President and Vice President, Members of } \\
\text { the People's Legislative Assembly, Regional } \\
\begin{array}{l}\text { Representatives Council, and Regional People's } \\
\text { Representative Council }\end{array}\end{array}$ & 2019 & 1134279 & $80,05 \%$ \\
\hline
\end{tabular}

Source: Processed by researchers.

From the table above, it can be seen below in the 2004 General Elections, the level of voter participation in voting rights was $78.69 \%$ of the total voters of $1,031,392$ male and female voters. Election of President and Vice President In 2004, the first round of voter community participation rate in using their voting rights was $78.71 \%$ of the total voters of $1,076,118$ male and female voters, while in the second round the voter community participation rate in using their voting rights was $78,60 \%$ of the total voters were $1,052,047$ male and female voters.

Election of Mayor and Deputy Mayor of Semarang in 2005, the level of participation of voters in using their voting rights was $66.68 \%$ of 997,200 voters. Then in the General Election of the Governor and Deputy Governor in 2008, the level of participation of the voting community in exercising their voting rights was $62.74 \%$ from $1,086,521$ voters

General Election In 2009, the level of participation of voters in using their voting rights was $71.41 \%$ of the total voters of 1,087,463 male and female voters. Then in the 2009 General Election of President and Vice President, the level of participation of voters in using their voting rights was $78.79 \%$ of the total voters of $1,094,832$ male and female voters.

Election of Mayor and Deputy Mayor of Semarang in 2010, the level of voter participation in voting rights only reached $60.06 \%$ of the total electorate of $1,100,337$ male and female voters. Then in the General Election of the Governor and Deputy Governor in 2013 , the level of voter participation in voting rights increased to $61.44 \%$ of the total electorate of 1,125,696 male and female voters.

Elections In 2014, the level of voter participation increased to $75.15 \%$ from a total of 1,101,290 male and female voters. Then in the 2014 Presidential and Vice President Election the level of voter participation in the City of Semarang increased to $79.88 \%$ of the total number of voters in the 2014 Presidential and Vice President Elections amounting to $1,121,824$ people.

The Election of Mayor and Deputy Mayor of Semarang in 2015, the level of voter participation in voting rights only reached $65.67 \%$ of the total electorate of $1,109,045$ male and female voters. The political participation of the people developed well from the previous year at $60 \%$. In 2015, the Central Election Commission implemented so that all regions in the elections simultaneously achieved $75 \%$ participation. But it was denied by the City of 
Semarang that the $75 \%$ figure was not realistic for cities in the region. So the city of Semarang with a figure of $65.67 \%$ is a level of participation that increased from the previous year.

Likewise, the last election, namely the Election of President and Vice President, Members of the House of Representatives, Regional Representatives and Regional Representatives in 2019, the level of participation of voters in using their voting rights only reached $80.05 \%$ of the total electorate of $1,134.279$ male and female voters.

\subsection{The Factors that Cause the Rise and Fall of Public Participation in General Elections are}

First, a decrease in the level of trust in political elites (political parties) as a form of resistance to corrupt behavior by political elites.

Second, the critical factor, meaning that a critical community can analyze the results of the previous elections in realizing promises during the campaign. The level of realization of campaign promises which are relatively low and unable to accommodate and fight for the aspirations of the people is the basis for non-participation.

Third, political parties in the city of Semarang are less concerned about environmental problems in the city of Semarang, especially those related to tidal flooding and problems. Concerns that exist are still partial and incidental in nature, have not been embodied in an organizationally and comprehensively in official party documents, nor have they become the main and sustainable program.

Fourth, the factor of circumstances where the person (voter) cannot cast his / her vote at the Voting Place where he lives because the person is registered at another regional Voting Place For example, people who have migrated to other areas either to earn a living, study knowledge or other purposes.

Fifth, the time for political education/socialization on television, radio and other media is very short, this causes not all people to be able to watch the socialization.

Sixth, the socialization activities (Political Parties, General Election Commission of Semarang City) have been realized, but we do not impose the right to vote because it is the right of every citizen to vote or not. From that, we need to do our best to increase the political participation of the citizens of Semarang City.

Seventh, through online. Campaigns that take advantage of the candidate pair's official safe means, disseminate content on official social media accounts, virtual conferences (meetings), and broadcast live campaign activities. Especially in Semarang City, the campaign period as part of the regional head election stages began on September 26 and will end on December 5, 2020.

\subsection{Semarang City Government Strategy in Political Education}

Strategy according to Gregory [7] is an overall approach related to the implementation of campaign program planning within a certain period of time, coordinating the work team, having themes, supporting factors that are in accordance with the principles for implementing strategic ideas rationally and can be implemented through a Public Relations campaign program tactics effectively and efficiently. In developing a communication strategy, it includes communicators, messages, communicants, media, and feedback. The strategy for providing political education refers to 4 stages, namely:

First, Research, Morrisan [8] Based on the findings in the field, he has conducted a series of data-seeking activities before compiling his work program. The first action a PR 
practitioner (political party) should take before compiling a work program is to understand the situation or problem that exists. Public relations practitioners must do research / research first to get a comprehensive picture of the problems at hand.

Second, Planning, Morrisan [8] after finding a problem from a research that has been carried out, the next step is to determine a plan, namely the steps that must be taken to solve the problems encountered. Planning is an important part of work, because it is a series of work carried out after data collection. Careful planning is important to determine the next steps related to problems that arise then try to provide appropriate solutions to these problems. In planning a program, the first thing to do is set goals. The goals to be achieved depend entirely on the size of the capacity and resources that are owned itself meanwhile, the objectives to be achieved in the political education strategy are: (a) Increasing voter participation, both in quality and quantity, in the entire election process. (b) To become a center for electoral information. (c) So that the public knows that the election/Pilkada is a golden bridge for government administration. (d) Indonesia during a certain period of government in Indonesia, namely 5 years.

Educating the public about the importance of elections and democracy by: Introducing the values, basic values of elections and democracy (pre-voters). Such as: (a) Elementary School Students-Senior High School. (b) Increase understanding of the importance of democracy (all segments). Such as: Students from Elementary Schools-Senior High Schools/equivalent, Diploma 1 (D1) Students-Postgraduate/Strata 3 (S3) and the General Public. (c) Instilling awareness of democratic values (all segments). Such as: Students from Elementary Schools-Senior High Schools/equivalent, Diploma 1 (D1)-Postgraduate Students (S3) and the General Public.

Third, Communication, after doing research and planning, the next step is communication or program implementation. A well-prepared plan as a result of careful thought based on the data that has been obtained, then communicated. The government must be able to communicate program implementation so that it can influence public attitudes which then encourage them to take action.

Proactive, Stephen [9] is an organization that has many actions that lead to positive things. Proactive organizations always have stimulation, awareness, imagination, conscience, free will and have a response but have a choice to do something that is positive. Reactive is an act of an organization that has a response to something or what is called a stimulus or stimulus.

Fourth, Evaluation, Abdurachman [10] in providing education about political education, especially voter education related to general elections, either from direct (face-to-face) or indirect (online website) resource delivery and enthusiasm or public response. The evaluation is then packaged in the form of periodic reports in the form of visits and developments which are held 3 times during 1 year as determined by the General Election Commission of the Republic of Indonesia. The main purpose of evaluation is to measure the effectiveness of the overall process. At this stage, public relations are required to be thorough and thorough for the sake of accuracy of existing data and facts, evaluation can be carried out continuously and the results of the evaluation will become the basis for subsequent public relations activities. The use of the right strategy is one of the important things that must be done by the General Election Commission of Semarang City in carrying out political outreach. The political outreach strategy in Regional Head Elections is used to realize political ideals that lead to changes in society for the better, such as increasing knowledge, understanding and public awareness of their voting rights in Regional Head Elections. In order to increase voter participation in the Semarang City General Election, various efforts, efforts and actions are 
needed by the Semarang City General Election Commission as the organizer of the General Election. The use of the right strategy will ultimately lead to activities that are more concrete, specific and can be implemented in the field. The main objective of the strategy is in principle the achievement of targets.

\subsection{Political Education Strategy for the Covid-19 Pandemic}

The peace campaign in question is peace with Covid-19, the signing of an integrity pact that states candidate pairs must obey the General Election Commission Regulations and implement health protocols. All outdoor activities such as public meetings, music concerts are no longer allowed. Activities can be done but must be virtual, but if indoors the activity is limited to 50 people with the Health protocol. Political participation strategies in simultaneous regional head elections during the Covid-19 pandemic in Semarang City, through online campaigns and conventional campaigns.

First, Online Campaign Strategy. The campaign method that is most encouraged to be carried out during a pandemic is the least online campaign. Among the obstacles are, the internet network in the regions that is not very supportive, the limited quota of participants and campaign organizers, the limited ability to use the devices of participants and campaign organizers. Furthermore, the limited features in the device and online campaigns were less attractive, so that few campaign participants participated. Online campaigns, namely campaigns that take advantage of the candidate pair's official website, distribute content on official social media accounts, virtual conferences (meetings), and broadcast live campaign activities. Especially in Semarang City, the campaign period as part of the regional head election stages began on September 26 and will end on December 5, 2020. The campaign period at the 2020 Concurrent Regional Head Election faces various challenges because it takes place in the midst of the Covid-19 pandemic. The campaign, which is usually synonymous with mass gathering, has become difficult to carry out because it is feared that it could increase the risk of spreading Covid-19

If it has to be done face-to-face, it must be done with very strict health protocols in accordance with applicable regulations. Based on the General Election Commission Regulation Number 10 of 2020 to anticipate the spread of Covid-19 in holding the 2020 Regional Head Election, there are several rules that must be considered by all related parties. For example, the question of limiting the number of participants, implementing strict health protocols, controlling physical distancing and so on are needed to prevent the spread of Covid19.

The next challenge is a matter of culture, because there are still people who are not familiar with the tradition of online campaigns so massive and well-targeted socialization is needed. In addition, what is most important and needs to be underlined is how to create an effective online campaign that is engaging, interactive and can attract people's attention. Because the problem is not just network infrastructure and access, but how to create content that is of interest, so online campaigns are ultimately a content battle. In an online campaign, creativity is absolutely necessary. The rule is, who can create conversation, he will exist, because conversation will encourage "Engagement" or attachment, while netizen characters get bored easily. People as voters are less interested in formal and rigid things. A less creative campaign will be less binding.

Thus, the key to online campaigns is a matter of creativity, about interesting content that can generate interactions and attachments, creativity is the root of that interaction. Moreover, if the regional head election participants use social media in online campaigns, social media 
has an interactive basic character, so if it fails to create interactivity, it means failing to take advantage of social media. This is different from the mass media. In the mass media, there is almost no feedback or 'feedback' or has a break. Meanwhile, social media can be 'real time' and interactive. Commentary columns on social media can be an example of a vehicle for interaction with netizens, for example 'feedback' that must be responded to.

Second, Campaign Conventional. It is feared that the conventional campaign will increase the risk of spreading Covid-19 if health protocols are not followed. Therefore, it is very necessary to have alternative efforts to avoid crowds in face-to-face campaigns. Apart from online campaigns, there are also other alternatives, for example the use of local media such as radio and television. If what is concerned is that not all areas have adequate internet infrastructure, then use local media such as radio and television, which are available in every area, and can reach even remote villages.

Socialization on the importance of strengthening online campaigns is still ongoing. However, there are also face-to-face campaigns, mainly due to various considerations, one of which is a matter of regional conditions. This face-to-face campaign is still allowed as long as the participants in the regional head election ensure that the activity meets the strict health protocol requirements as stipulated. His party continues to socialize so that regional head election participants can ensure there are no violations of health protocols during the campaign period.

At this time, various regulations have been well prepared, socialization has also been carried out massively, it is hoped that there will be joint awareness to realize a safe election in the midst of the Covid-19 pandemic, including strengthening online campaigns. In the end, in order to be able to run effectively, the regional head elections participants must, of course, have to develop a content battle strategy in online campaigns, think of ways to make the content produced can attract various groups. Uniquely and of course interesting strategies that are right on target will make online campaigns very influential, due to the fact that virtual interactions are now becoming more and more certain.

The success of achieving these goals is largely determined by the performance of the General Election Commission of Semarang City as the main actor in implementing the Election in synergizing all existing potentials, including human resources, funds and stakeholder support in the General Election Integrity and harmony in managing all these elements are contained in the political outreach strategy of the Semarang City General Election Commission which is then implemented in various activities, in order to increase public knowledge, understanding and awareness in using their voting rights which in turn can increase voter participation in election.

\section{Conclusion}

First, the implementation of political education carried out by the Semarang City government has not run optimally. This is indicated by the results of research which show that their role has not been maximized in providing the information needed for the implementation of public political participation, so that it has not had a significant impact/influence on political participation, especially the political participation of the younger generation in political activities. Second, the democratic communication system is still not optimal. The format of a public consultation forum with dialogical communication needs balance and equality between the community and the Semarang City government. Third, in the simultaneous regional head elections during the Covid-19 pandemic in the City of Semarang, 
through an online campaign, so that all people's aspirations can be easily conveyed as an effort to strengthen the democratic communication system. Fourth, the media (political parties) as an aggregation of the interests of the people, must be even harder to build a communication system, one of which is when collecting public aspirations in public consultation forums. Because the public consultation forum is a media for direct meetings between the Regional People's Representative Assembly and the community, it is hoped that it can become a medium for building real communication about problems that occur in society.

Fifth, the implementation of political education is carried out using various methods and strategies, including: training and coaching activities, seminars, studies, socialization and social activities. The implementation is determined according to the right conditions, scheduled and routine, but it does not rule out the activities to be adjusted to the existing conditions.

\section{Recommendations}

First, the policy subject society. In the current era of democracy, society is no longer an object but a subject of policy. Participation from the public is needed to control, evaluate and provide input to both the legislative and executive institutions.

Second, increasing the role and participation, the activeness of all elements of society in providing feedback and input in the implementation of general elections.

Third, the need for the younger generation to be given wider opportunities and responsibilities in the public sphere, such as being involved as members of political parties or other socio-political organizations. Fourth, E-Vote in the context of direct elections, the EVote concept is very likely to be applied, during the Covid-19 pandemic. The E-Vote concept can support the realization of direct elections that are effective and efficient, and minimize the potential for vote count manipulation.

\section{References}

[1] K Rusadi, Sistem Politik Indonesia Suatu Model Pengantar. Bandung: Bandung: Sinar Algensindo, 2004.

[2] M. Budiardjo, Dasar-dasar Ilmu Politik. Jakarta: PT Gramedia Pustaka Utama, 2010.

[3] S. Al-Muchtar, Pengembangan Kemampuan Berpikir dan Nilai dalam Pendidikan IPS. Bandung: Gelar Pustaka Mandiri, 2000.

[4] A. AR, Pendidikan Islam Kontekstual. Yogyakarta: Pustaka Pelajar, 2012.

[5] H. H. Soche, Supremasi hukum dan prinsip demokrasi di Indonesia. Jakarta: Gramedia Pustaka Utama, 2008.

[6] M. BN, Kamus Politik. Jakarta: CV. Mulya Sari, 2005.

[7] A. W. Gregory and B. E. Hansen, "Residual-based tests for cointegration in models with regime shifts," J. Econom., vol. 70, no. 1, pp. 99-126, 1996.

[8] M. A. Morissan, "Manajemen Media Penyiaran," Jakarta Prenada Media Grup, 2008.

[9] S. R. Covey, "The 7 Habits of Highly Effective People, terj," Budijanto, Jakarta Bin. Aksara, 1997.

[10] Abdurachman, Dasar-Dasar Public Relation,. Bandung: PT Citra Aditya Bakti, Bandung., 2010. 